present forest area in Southern Ontario both for production and use by people. To back this need he quoted from Isaiah Ch. 8/5: "Woe unto them that join house to house and field to field till there be no place in the midst of the earth". He stressed that European experience had shown that new and better laws will be required to prevent destruction of woodlands in Ontario and listed in some detail what these laws should be.

Mr. R. B. Loughlan, Secretary Manager of the Ontario Forest Industries Association, spoke on how the industry is affected by public opinion and government policies regarding the production of forest products. The industry acknowledges the need for regulations, but is concerned that unreasonable restrictions would unduly increase wood costs and affect their ability to compete in world markets. The Ontario forest industry recognizes that people want more access to forest lands for recreation, so the industry has opened many of its logging roads to the public.

Professor Erik Jorgensen of the Shade Tree Research Laboratory, University of Toronto, outlined how forest lands could be managed for intensive recreation. Comparing Ontario to his home land, Denmark, he said that Ontario had truly vast areas of forest and these could be managed to provide for all needs. To do this, foresters must establish communication with all forest users, contribute to their knowledge, and show leadership in providing for their needs.

Mr. G. Henderson, Executive Director of the National and Provincial Parks Association, spoke on his concern about forest management in parks. He believed that parks should be managed for "park values" - all those things that parks can provide, such as recreational, cultural, educational and scientific values. He was critical of present commercial

\title{
'Kiwi' strips make for efficient forest fertilization
}

Urea fertilizer has been applied in operational scale trials in recent years to young second growth stands of Douglas-fir in Coastal British Columbia forests.

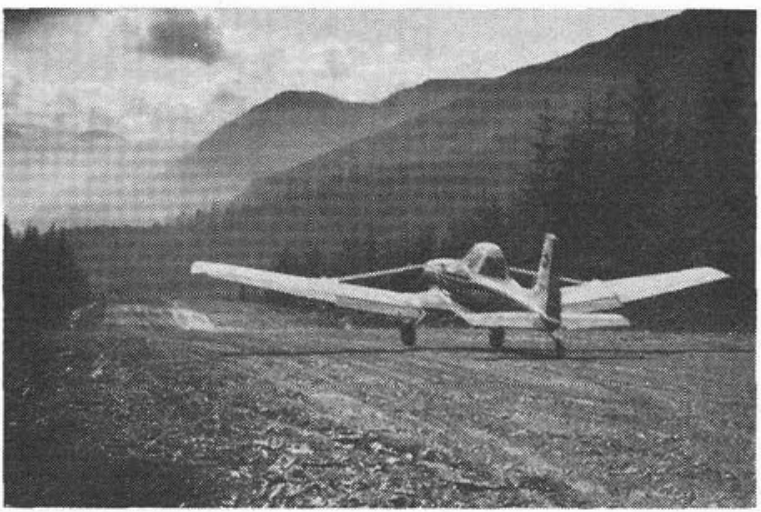

Conair's Cessna Agwagon at the 19 Creek strip. (Photo Alan Vyse, CFS.)

In the early years of Pacific Logging Company's trials, expensive conventional airstrips were used. The operation was far from efficient. Distances from the airstrip to the drop areas were too great and the loaded planes often had to climb some 2,000 feet. By the fall of 1968 it was obvious that to be economic, fertilizer application using fixed-wing aircraft required development of improved procedures.

The idea of constructing inclined airstrips as used in New Zealand was proposed by Mr. Jim Evans, Agricultural Manager for Conair Aviation.

In the winter of 1968 the first 'Kiwi' strip to be built for forestry purposes was roughed out at 19 Creek in the Robertson River valley on Vancouver Island. Final grading was carried out in June 1969. The site selected was at $1,100 \mathrm{ft}$ above sea level and $500 \mathrm{ft}$ above the valley floor. The strip was $840 \mathrm{ft}$ long, including the loading area at the top of the slope. The lower two thirds had an $8-10 \%$ slope whilst the upper third averaged $12 \%$.

In the fall of 1969,314 tons of urea were applied to second growth stands in $4 \frac{1}{2}$ days. In the spring of 1970, the strip was also used for seeding by fixed-wing aircraft. Maximum flight distance for the operation was $3 \frac{1}{2}$ miles from the strip.

Advantages of this kind of strip are:

1/ Low construction cost - the costs of six such strips so far built in B. C. Coastal Terrain range from $\$ 160$ to $\$ 1,700$.

2/ Sites suitable for building such strips can be located in close proximity to operating areas.

3/ Pilot fatigue factor is lower than for conventional level strips.

4/ Down time due to adverse winds is much less than for conventional strips.

5/ The technique is safe - some 1,274 landings and takeoffs have been made from inclined strips without mishap.

6/ At 1,000 lb per load an experienced pilot will spread 10 tons of fertilizer an hour.

7/ Landing, loading and take-off are accomplished in 50 seconds!

Seeing is believing - Conair Aviation and Pacific Logging Company Limited plan to demonstrate the technique to delegates attending the CIF Annual Meeting on October 19, 1971.

M. Crown, Forester Pacific Logging Company Limited 